\title{
"Shareholders' activism as a moderator of the relationship between corporate governance and return on investment"
}

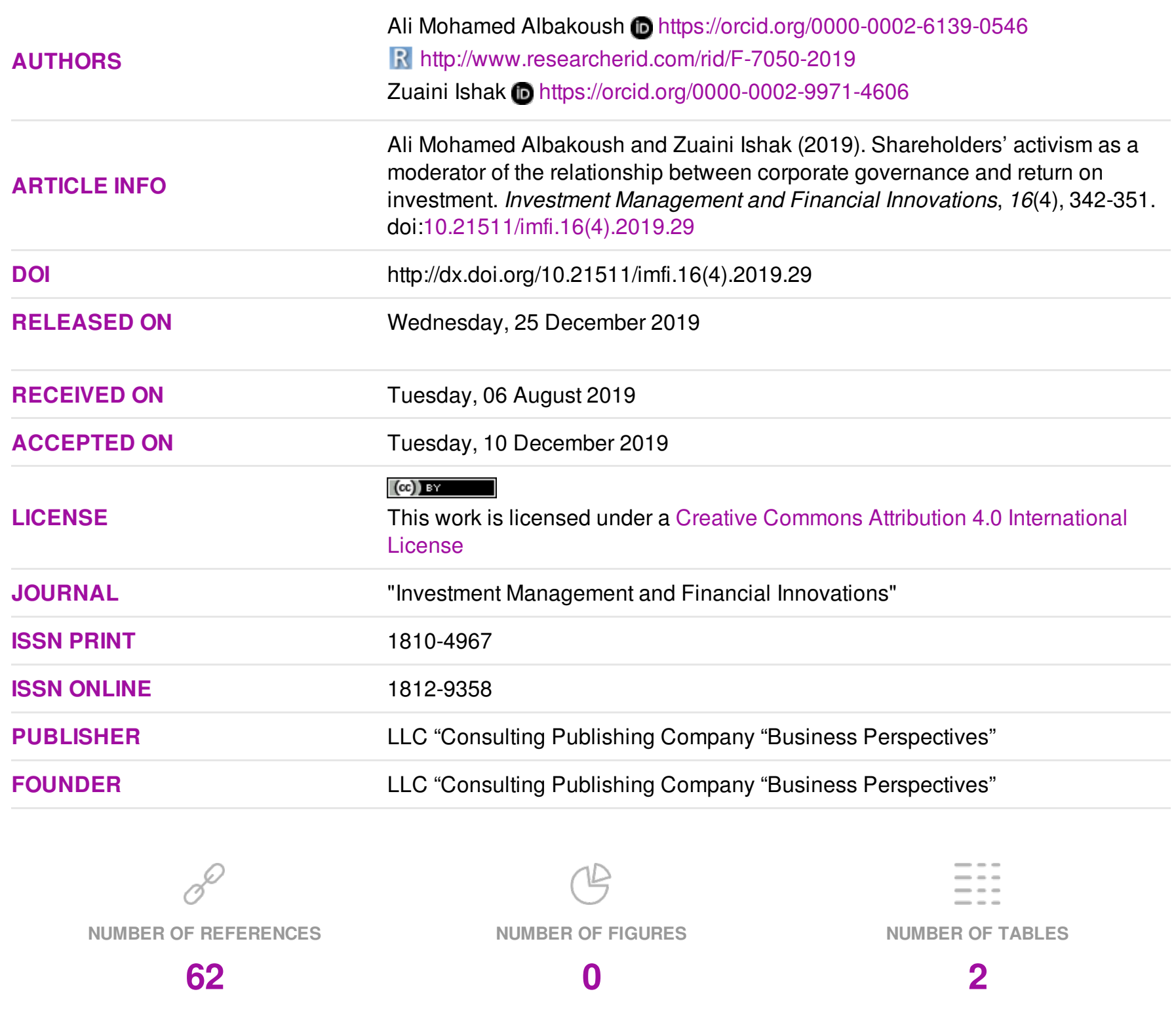

C The author(s) 2023. This publication is an open access article. 


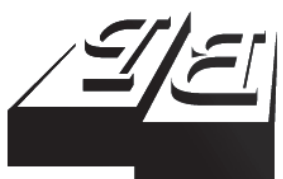

BUSINESS PERSPECTIVES

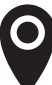

LLC "CPC "Business Perspectives" Hryhorii Skovoroda lane, 10, Sumy, 40022, Ukraine

www.businessperspectives.org

Received on: $6^{\text {th }}$ of August, 2019 Accepted on: 10 ${ }^{\text {th }}$ of December, 2019

(c) Ali Mohamed Albakoush, Zuaini Ishak, 2019

Ali Mohamed Albakoush, Ph.D. student, Tunku Puteri Intan Safinaz School of Accountancy (TISSAUUM), UUM College of Business, Universiti Utara Malaysia Assistant lecturer, Department of Accountancy, Economy faculty, AlAsmarya University, Libya.

Zuaini Ishak, Dr., Associate Professor Tunku Puteri Intan Safinaz School of Accountancy (TISSA-UUM), UUM College of Business, Universiti Utara Malaysia, Malaysia.

\section{(ㄷ) (i)}

This is an Open Access article, distributed under the terms of the Creative Commons Attribution 4.0 International license, which permits unrestricted re-use, distribution, and reproduction in any medium, provided the original work is properly cited.

\section{SHAREHOLDERS' ACTIVISM AS A MODERATOR OF THE RELATIONSHIP BETWEEN CORPORATE GOVERNANCE AND RETURN ON INVESTMENT}

\begin{abstract}
The purpose of shareholders' involvement in the process of governance is to add corporate value and achieve better governance and firm performance (FP). However, corporate governance (CG) practices can vary from country to country and change over time. This study examines the moderating influence of shareholders' activism (SA) on the CG effectiveness - FP relationship in non-financial companies listed in the Libyan Stock Market between 2007 and 2016. CG effectiveness was the independent variable and consisted of five dimensions: board of directors, monitoring committee, audit committee, nomination and compensation committee, and ownership. Leverage, firm age and firm size were used as control variables. Return on investment was used to assess the corporate performance. SA was tested as a moderating variable using the interactive regression models. The study found out that the CG effectiveness is positively and significantly related to return on investment (beta $=0.608, \mathrm{p}<0.01)$. This relationship was strengthened by SA $(\mathrm{R} 2=0.053, \mathrm{P}<0.05)$. Overall, the study shows that $\mathrm{SA}$ boosts the relationship between CG and FP in the Libyan Stock Market.
\end{abstract}

\section{Keywords}

shareholders' activism, corporate governance, firm performance, Libya

\section{JEL Classification G34, G38, M14}

\section{INTRODUCTION}

Managers' interests might deviate from the interests of shareholders (Eisdorfer, Giaccotto, \& White, 2015). Therefore, a framework of governance is needed to encourage the managers to pursue the objectives that maximize the shareholder wealth. Different governance forms have been created to minimize the agency expenses (Florackis, 2008). However, previous researches on the relationship between CG mechanisms and FP have provided the inconsistent results (Ahmed \& Hamdan, 2015; Chandren, Ahmad, \& Ali, 2015; Narwal \& Jindal, 2015). Legal, regulatory, and institutional environments, and historical and cultural factors, could also influence the CG - FP relationship.

An effective governance system can minimize the cost of the agency problem by aligning the managers' and shareholders' interests, thereby strengthening the shareholders' rights and their ability to monitor the management of the firm (Chauhan, Lakshmi, \& Dey, 2016). Thus, effective CG would respond to SA to enhance FP.

Though the forms and exercise of activism by shareholders could vary due to the different environmental and legal contexts, SA is driven by their interests (Coffee \& Palia, 2014). There is some controversy about the impact of different forms of SA (proposals and negotiations) on FP 
and on changing governance policies (Cunat, Gine, \& Guadalupe, 2015; Gillan \& Starks, 2000; Grewal, Serafeim, \& Yoon, 2016). Furthermore, efforts to protect the minority shareholders may be hindered by ownership concentration, which might cause the expropriation of minority shareholders' rights (Santiago-Castro \& Brown, 2007). Free-ride shareholders, such as government-controlled shareholding, may limit or eliminate the influence of minority shareholders on managerial decision-making. However, scanty reports are available on SA practices and influence in the developing countries.

SA includes the negotiation with the firm's executive managers or board directors about shareholders' investment concerns (Welker \& Wood, 2011). Proposals from shareholders have been widely used by various investors, such as institutional investors, social coordination groups, and individual investors to challenge the managers and directors, direct attention, and raise awareness (Cziraki, Renneboog, \& Szilagyi, 2010). Shareholders' proposals inform the management about the issues that deserve attention. Also, vote-no campaigns represent a means by which the shareholders communicate their dissatisfaction (Del Guercio, Seery, \& Woidtke, 2008). SA might also involve posting the questions to firm management and asking for answers (Lafarre \& Van der Elst, 2018).

Worldwide, there are differences in how much impact the shareholders can have on governance practices. The legal and cultural framework may allow SA to have leverage on corporations and boards of directors (Sharfman, 2014).

Some research reported that high financial performance level is associated with SA, whereas others found little impact (Del Guercio et al., 2008). However, only a few studies have addressed the country-specific aspects of SA.

SA in Middle Eastern countries crept in with the recent establishment of stock markets and CG codes in most of the Arab countries (Piesse, Strange, \& Toonsi, 2012). According to the Libyan corporation law of 2010, shareholders and minority shareholders have a right to attend annual general meetings and to vote on resolutions under discussion. A report from Tunisia confirmed the influence of SA on the firms' policies (Guizani, 2014). However, to our best knowledge, there is no empirical study on the influence of SA on the relationship of CG with FP in any Arab country.

This study examined whether SA has a moderating effect on the relationship between the efficacy of CG and return on investment of firms in the Arab, North African, oil-rich country of Libya. The study shows that in Libya SA strengthens the relationship between the effectiveness of CG and return on investment in Libyan non-financial companies.

\section{LITERATURE REVIEW}

SA evolved over several decades from the chance to submit resolutions (Reid \& Toffel, 2009) and media usage (Ragas, 2013) to filing lawsuits to pressure the companies to adopt the changes and ultimately enhance the societal impact, but without gaining any control (Proffitt \& Spicer, 2006).

SA is mainly governance financial activism seeking to enhance the governance framework and render firm management more responsible to the interest of shareholders (Thomas \& Cotter, 2007). Nevertheless, SA also uses market ways to influ- ence the corporations and maximize the shareholder value (Cheffins \& Armour, 2011).

SA may be seen as reactive governance activism: shareholders observe and react to governance deficiencies (Cheffins \& Armour, 2011), voice their discontent with CG or FP (Becht, Franks, Mayer, \& Rossi, 2009), or exercise their rights to pressure management to take specific steps to improve the shareholder value (Gantchev, 2013). Modern portfolio theory, from the investors' perspective, illuminates the shareholders' motivation to participate in activism (Rubach \& Sebora, 2009). Corporate social responsibility and institutional 
theory examine the spread of activism and its influence on firm frameworks and social responsibility (Reid \& Toffel, 2009). Political theory explains the managerial role in SA (Jensen, 1993). Social influence theory, reactance theory, and stakeholder theory explain the managers' propensity to accommodate the demands by shareholder activists (Parthiban, Bloom, \& Hillman, 2007; Davis \& Thompson, 1994). Stakeholder theory challenges the agency theory by disputing the shareholders' importance with a broader view that a firm has an obligation to all stakeholders (Freeman, Wicks, \& Parmar, 2004) and the principal-agent conflict with the ethical principles of trust, trustworthiness, and cooperativeness (Jones, 1995). Goranova and Ryan (2014) argue that the agency theory is probably evoked more often when speaking of SA than any other competing theoretical framework.

Good CG practices enable an efficient monitoring system for firm management and performance (Bhagat \& Bolton, 2008), and thereby SA can help to maintain effective CG (Chung \& Zhang, 2011). Also, national laws guarantee the shareholders' rights and empower SA to influence decision-making, promote better governance, and increase shareholder return. The shareholders' rights commonly regulated by laws include the right to share in profitability, influence the selection of managers, and vote in the annual corporate general meeting. Shareholders' rights to influence the company management and to form the coordination groups enable the shareholders to influence the governance mechanisms to promote positive firm value. Shareholders' rights also encourage the management to pursue the growth of the firm rather than focus on quick returns or self-interest (Jiang \& Anandarajan, 2009).

SA can take place in many forms, such as private discussions, public debate with the firm's management or directors, press campaigns, shareholder resolutions, call for general meetings, seeking to replace directors, taking legal proceeding, etc. (Filatotchev \& Dotsenko, 2015). Shareholder proposal, shareholder vote-no, and shareholder negotiation improve the management performance and shareholders' value (Filatotchev \& Dotsenko, 2015).

Submitting the proposals on governance issues is a common form of SA in the United States, while proposals are uncommon in Europe (Cziraki et al., 2010). In Europe, private negotiation with management on the governance framework is a common practice (Cziraki et al., 2010). In some Arab countries, more public governance frameworks have been adopted, but not much is known about the activism of the shareholders (Baydoun, Maguire, Ryan, \& Willett, 2012). Decision-making among Arabs is deeply affected by informal relationships and tribal affiliations.

SA facilitates the shareholders' interests and priorities, improves the CG and mitigates the monitoring costs (Zeng, Yuan, \& Zhang, 2011).

\subsection{Shareholders' monitoring}

Shareholders may contribute to and boost the monitoring function of the governance framework, increase the governance effectiveness and, from the theory's perspective, limit the agency problems. The lack of sufficient shareholder engagement in the monitoring function may be related to much corporate misbehavior (Clapman, 2005). Obermann and Velte (2018) argue that the increase in shareholder responsibility and shareholders' monitoring role improves the efficiency of governance and maximizes the company's values. Thus, the increase in monitoring by shareholders reduces the default risks of management behaviour, increases the integrity of financial accounting reports, and alleviates the extent of information asymmetry between firms and debt issuers, and consequently improves the FP.

Most capital markets force the listed firms to increase their engagement with shareholders and large minority shareholders to mitigate the agency problem and implement the good governance. Representation of shareholders in the board facilitates the monitoring by shareholders (Pasquali, 2015). Monitoring by shareholders through vote-no campaigns has significantly reduced the CEO payments in UK firms in which the pay was excessive (Ertimur, Ferri, \& Muslu, 2011). Sunder (2014) found that SA helps the debtholders reduce the credit risk. Thus, SA is linked to monitoring tools such as appointment or replacement of directors, board composition, compensation packages, incentive schemes, and 
strategic issues that may affect shareholders' rights and their interests (Mallin, 2012).

Thus, the monitoring function of SA imposes control through involvement and engagement in firm management, provides the board with feedback, hinders poor governance, enhances the firm's performance, and affects the market prices of firms.

\subsection{Moderating model of Shareholders' Activism (SA)}

Literature review revealed that researchers studying the CG - FP relationship reported the mixed results (Bhatt \& Bhatt, 2017; Detthamrong, Chancharat, \& Vithessonthi, 2017; Zabri, Ahmad, \& Wah, 2016). The direct influence of effective governance by the of directors board is on the quality of their supervision of senior management, the operations of the firm, and the process of decision-making. This quality of supervision consequently improves the FP. However, the influence of governance dimensions could be indirect. Such an indirect relationship could explain why some researchers have reported no significant relationship of measures of governance with FP (Buallay, Hamdan, \& Zureigat, 2017).

CG codes worldwide emphasize the shareholders' rights as governance practices. Hence, SA can moderate the relationship of governance dimensions to FP. A study on the moderating roles of CEO duality and board independence found that they were significant moderators of the relationship of ownership structure and FP (Sulong \& Nor, 2010). In another study, CEO power was found to moderate the board composition and FP relationship (Combs, Ketchen, Perryman, \& Donahue, 2007). Elsewhere, no moderating effect of independence of the board of directors on the CEO duality and FP relationship was found (Hsu, Wang, Tsai, \& Lu, 2012).

The inconsistency among these studies could be because of the absence of inclusive representation of the essential variables of governance practices. Inclusion of SA as a moderating study variable in testing the governance dimensions and FP relationship would also be necessary when examining the influence of governance practices on the performance of firms.
This literature review provides the evidence for the presence of a relationship between FP, governance practices, and SA. Moreover, the SA role in monitoring the board of directors increases the market value of the company, especially when the board practices democracy and shareholders are allowed to benefit from proxy access. Campbell (2012) argues that boards are currently aligned with managers rather than with shareholders. Most CG codes recommend the establishment of monitoring committees. Nevertheless, the governance practices' relationship to FP is most likely indirect, with SA moderating this relationship. Only few studies have addressed the characteristics of governance and activism of minority shareholders in the developing countries.

\subsection{Paper framework}

The research framework was developed to show the moderating effect of SA on CG effectiveness and FP relationship. SA is expected to positively influence this relationship. Hence, the conceptual framework in this paper examines the relationships among the primary conceptualized constructs, including their proxies. This study addresses the gap in the knowledge of the influence of SA as a moderator of the CG effectiveness - FP relationship. The findings were used to better understand the attributes of CG mechanisms in Libya.

\subsection{Hypotheses}

The board possesses the right to oversee and govern company management on the owners' behalf. Nevertheless, these rights are limited, as some board decisions need the shareholders' approval. When shareholders' and directors' interests are not aligned, shareholders use their rights to interact with upper management and might vote "No" on controversial board decisions. From the agency theory perspective, such monitoring roles of SA improve and preserve the governance effectiveness and enhance the FP. Thus, SA could be studied as a factor that moderates CG to enhance the firm value. In this study, we hypothesize that SA positively moderates the relationship between the efficacy of CG and return on investment in listed non-financial companies. 


\section{METHODOLOGY AND DATA COLLECTION}

\subsection{Sample}

A total population purposive sampling technique was used. All non-financial companies listed in the Libyan Stock Market were included in the study. Data were collected from all 42 Libyan listed non-financial companies for the years 20072016. Information on the board's characteristics and its committees (monitoring committee, audit committee, nomination and compensation committee) and ownership structure were acquired from the Libyan Stock Market, the databases of the boards and shareholders, and the companies' financial reports.

During the study period, 413 observations were made. The ownerships of 42 firms were classified as governmental or private ownership. Leverage, firm size, and firm age were deemed as control factors.

The independent variable was CG effectiveness (CGE), and the dependent variable was return on investment (ROI) as a measure of financial performance. The definitions of the variables and the data sources are shown in Table 1. The CGE score is a composite score for the characteristics of the board, the monitoring committee, the audit committee, and the nomination and compensation committee. The CGE score is deemed to give a better measure of the influence of CG on FP (Bauer, Frijns, Otten, \& Tourani-Rad, 2008).

\subsection{Statistical methods}

IBM-SPSS version 25 was used. The median and range and mean and standard deviation (SD) are reported. The relationship between the dependent variable (ROI) and independent variable (CGE) was determined by weighted linear regression models. Moreover, SA was regressed as a variable moderating the relationship between ROI and CGE.

$$
\begin{aligned}
& R O I_{i t}=\beta_{0}+\beta_{1} C G E_{i t}+\beta_{2} P O W N_{i t}+ \\
& +\beta_{3} F S I Z E_{i t}+\beta_{4} L E V_{i t}+\beta_{5} F A G E_{i t}+ \\
& +\beta_{6} S A_{i t}+\beta_{7}(C G E \cdot S A)_{i t}+e_{i}+u_{i t},
\end{aligned}
$$

where $R O I$ - return on investment, $C G E$ - effectiveness of CG, POWN - private ownership, FSIZE - firm size, $L E V$ - leverage, FAGE firm age, $S A$ - SA, $e$ - error term, $U$ - composite error for the estimation, $i$ - indicating firm data, $t$ - time.

The analysis was performed in four steps. First, the control variables were included (firm age, firm size, leverage, and ownership structure). Second, the independent variable (CGE) was added, followed by SA (step 3). The moderating effect of SA was tested in the fourth step. The moderating effect factor was determined by the change in $R^{2}\left(\Delta R^{2}\right)$ in the model of regression, where the independent and moderating variables were included simultaneously.

\section{RESULTS}

The mean, median, and range of the dependent variable (ROI) were $0.57,0.47$, and from -0.98 to 8.85 , respectively. CGE had a mean of 0.32 , a me-

\begin{tabular}{|c|c|c|}
\hline Variable & Definition/measurement & Source \\
\hline \multicolumn{3}{|c|}{ Independent variable } \\
\hline Effectiveness of CG & Composite of good CG practices & Board's database \\
\hline \multicolumn{3}{|c|}{ Dependent variable } \\
\hline Return on investment & Operations profit $\div$ investment costs & Financial reports \\
\hline \multicolumn{3}{|c|}{ Moderating variable } \\
\hline SA score & $\begin{array}{l}\text { Consists of shareholder "vote-no" shareholder proposals, and shareholder } \\
\text { negotiation with management }\end{array}$ & $\begin{array}{l}\text { Board's and shareholders' } \\
\text { databases }\end{array}$ \\
\hline \multicolumn{3}{|c|}{ Control variables } \\
\hline Firm size & The natural logarithm of the book value of total assets & \multirow{3}{*}{ Financial reports } \\
\hline Firm age & Number of years since the company's establishment & \\
\hline Leverage & Total debt divided by total equity & \\
\hline
\end{tabular}
dian of 0.30 , and a range of 0.1-0.7.

Table 1. Definitions/measurement of the variables and data sources 
All 42 companies had joint private-public ownership, but private ownership was dominant, on average accounting for $76 \%$ of ownership (standard deviation $=0.42$ ).

While the control variable, firm size, was more uniformly distributed, there was wide variation in firm age (range $1-66$ years, $\mathrm{p}<0.001$ ) and leverage (range $0-4.23, p<0.001$ ).

We found three forms of SA among 42 companies: vote-no shareholder proposal, and shareholder negotiation. As shown in Table 3, the frequencies of three types of SA varied widely between the listed companies (median 2.5, range 0.92-4.33, mean 2.49).

Table 2 shows that CGE in the Libyan market was positively related to financial performance as measured by ROI (Step 2: beta $=0.608, p<0.01$ ) . More specifically, one unit increase in the CGE score was associated with a $60.8 \%$ increase in ROI. Also, one unit increase in the score of SA effectiveness was associated with a $10.6 \%$ increase in ROI (Table 5, Step 3). The interactive effect of SA significantly increased the strength of the correlation between CGE and ROI by $5.3 \%\left(\Delta R^{2}=0.53, p=\right.$ 0.001 , Step 4 , Table 5). These results demonstrate that effective SA strengthens the CGE and ROI relationship.

\section{DISCUSSION}

This study, which, to the best of our knowledge, is the first of its kind in the Middle East and
North Africa, describes SA as a moderator of the relationship between CG and FP. Nevertheless, research on $\mathrm{SA}$ in the emerging economies is scanty (Othman \& Borges, 2015).

In agreement with other studies (Chauhan et al., 2016; Singh, Tabassum, \& Darwish, 2017), we found that more effective CG yields better ROI. Notably, we found that SA has a significant positive moderating influence on the CGE and ROI relationship in Libya. SA demands better governance and effective strategies (David, Hitt, \& Gimeno, 2001), and from the agency theory perspective, it adds value to a firm by shaping its governance policies and mitigating the conflict with management. However, the influence of SA also varies with the economic environment, the structure of ownership, and the type of SA. In general, each country is unique due to its firm ownership structures and legal, cultural, and social values (Bliss, 2012). In our study, the shareholders might have found that vote-no activism mediated their interests and priorities better than proposals and negotiations. However, a study in the United States found no evidence that SA has a positive influence on the market value of the firm (Bebchuk, Brav, \& Jiang, 2015). Moreover, whereas the shareholder proposals have been reported to have little effect on firms, an analysis of S\&P 1500 firms plus 500 widely-held firms showed that say-on-pay proposals by shareholders influence the FP (Cunat et al., 2015). Previous studies revealed that shareholder activists who own a substantial block of shares have more signifi-

Table 2. The results of the multivariate weighted least-squares regression analysis of four steps

\begin{tabular}{|c|c|c|c|c|c|c|c|c|c|c|c|c|}
\hline \multirow{3}{*}{ Variable } & \multicolumn{12}{|c|}{ Corporate performance } \\
\hline & \multicolumn{3}{|c|}{ Step 1} & \multicolumn{3}{|c|}{ Step 2} & \multicolumn{3}{|c|}{ Step 3} & \multicolumn{3}{|c|}{ Step 4} \\
\hline & B & SE & $T$ & B & SE & $T$ & B & SE & $T$ & B & SE & $T$ \\
\hline Constant & 1.397 & 0.244 & 5.735 & 1.693 & 0.253 & 6.680 & 1.588 & 0.277 & 5.724 & 1.637 & 0.270 & 6.069 \\
\hline Firm age & 0.002 & 0.003 & 0.645 & -0.002 & 0.003 & -0.705 & -0.003 & 0.003 & -0.881 & -0.004 & 0.003 & -1.158 \\
\hline Firm size & -0.096 & 0.029 & $-3.256^{* *}$ & -0.151 & 0.033 & $-4.614^{* *}$ & -0.146 & 0.033 & $-4.402 * *$ & -0.159 & 0.032 & $-4.919 * *$ \\
\hline Leverage & 0.017 & 0.015 & 1.122 & -0.020 & 0.018 & -1.106 & -0.013 & 0.020 & -0.643 & 0.003 & 0.020 & 0.163 \\
\hline Ownership & -0.149 & 0.055 & $-2.707 * *$ & -0.138 & 0.054 & $-2.545^{*}$ & -0.138 & 0.054 & $-2.536^{*}$ & -0.142 & 0.053 & $-2.695^{* *}$ \\
\hline CGE & NA & & & 0.608 & 0.167 & $3.632^{* *}$ & 0.602 & 0.168 & $3.593^{* *}$ & 0.114 & 0.190 & 0.599 \\
\hline SAE & & NA & & & 0.106 & 0.113 & 0.935 & 0.559 & 0.143 & $3.919^{* *}$ & & \\
\hline M-SA & & & \multicolumn{3}{|c|}{ NA } & 0.222 & 0.044 & $4.994^{* *}$ & & & & \\
\hline $\mathrm{F}$ & \multicolumn{3}{|c|}{4.29} & \multicolumn{3}{|c|}{6.175} & \multicolumn{3}{|c|}{5.290} & \multicolumn{3}{|c|}{8.364} \\
\hline$R^{2}$ & \multicolumn{3}{|c|}{0.040} & \multicolumn{3}{|c|}{0.071} & \multicolumn{3}{|c|}{0.073} & \multicolumn{3}{|c|}{0.126} \\
\hline$\Delta R^{2}$ & \multicolumn{3}{|c|}{-} & \multicolumn{3}{|c|}{0.031} & \multicolumn{3}{|c|}{-0.002} & \multicolumn{3}{|c|}{0.053} \\
\hline
\end{tabular}

Note: CGE: corporate governance effectiveness; SAE: SA score; M-SA: SA moderating; B: non-standardized regression coefficient beta; SE: standard error for beta; T: $T$ value for beta; NA: not applicable; ${ }^{* *} p<0.01 ;{ }^{*} p<0.05$. 
cant impact on firm value and corporate performance, probably due to their ability to vote "No." Also, Neubaum and Zahra (2006) found that SA moderates the relationship between ownership and corporate social performance. Furthermore, shareholding concentration is associated with important improvements in firm value and performance (Lee \& Park, 2009; Souha \& Anis, 2016).

Recent Libyan studies attributed the low CGE in Libya to the current political instability and lack of security (Abdou, 2015). This current situation has contributed to a reduction of foreign investment in Libyan companies and the absence of foreign companies. Nevertheless, despite these limitations, our study confirms the positive relationship between governance practices and the performance of a firm and shows the positive moderating effect of SA on this relationship.

Libyan firms should facilitate and encourage the engagement of SA in decision-making to enhance the CG and increase the financial performance. Such engagement of shareholders can also increase the firm market value, which would attract more capital and provide a beneficial business environment with a greater degree of investor confidence. The expected outcome would be an increase in stakeholders' wealth and the country's financial stability.

\section{CONCLUSION}

Libyan SA has a positive moderating effect on the relationship between CG efficiency and return on investment as a measure of firm financial performance. An increase in the effectiveness scores of CG and SA increases firm financial performance. Moreover, the interactive effect of effective SA strengthens the impact of CG efficiency on firm financial performance. This is in agreement with the agency theory's perspective of the importance of the monitoring roles of SA in preserving and improving the governance effectiveness of the board, the monitoring committee, the audit committee, and the nomination and compensation committee. Vote-no shareholder activism is used more often than shareholder proposal and shareholder negotiation in Arab countries to influence the effectiveness of CG.

Corporations in the region should facilitate and encourage the engagement of SA in decision-making to enhance the CG quality, increase the market value of firms, and provide a beneficial business environment with a higher degree of investor confidence. This would attract more capital, increase the stakeholders' wealth, and enhance the country's financial stability.

Other comparative studies would provide more insight into the impact of country-specific legal and social factors on the influence of SA on CG practices and FP.

\section{LIMITATIONS AND FUTURE RESEARCH}

The study is limited to the Libyan stock market, and although Libya has a tribal social structure resembling those in other countries in the Middle East and North Africa region, other political and economic differences could influence the practices of SA. Thus, future research is needed to compare the practices of governance and SA in several countries in the Middle East and North Africa and assess the impact of SA on CG practices and FP.

The study size is small, but it included all the non-financial listed companies, and so it is representative of SA among such companies. Future studies should examine the influence of SA when ownership is diverse. It is also worthwhile to investigate the influence of laws, organizations, and management information systems on SA effectiveness. 


\section{REFERENCES}

1. Abdou, M. A. (2015). Towards a new solution of minority shareholder protection in Libya: letting the minority shareholders have a voice (328 p.) (Ph.D. thesis). University of Glasgow. Retrieved from http://theses.gla. ac.uk/6423/7/2015AbdouPhD.pdf.

2. Ahmed, E., \& Hamdan, A. (2015). The Impact of Corporate Governance on Firm Performance: Evidence From Bahrain Bourse. International Management Review, 11(2), 21-37. Retrieved from https://pdfs.semanticscholar org/e182/e3df6a8d62fa362f9ce63047d64403084414.pdf

3. Bauer, R., Frijns, B., Otten, R., \& Tourani-Rad, A. (2008). The Impact of Corporate Governance on Corporate Performance: Evidence from Japan. Pacific-Basin Finance Journal, 16(3), 236-251. https://doi.org/10.1016/j.pacfin.2007.05.001

4. Baydoun, N., Maguire, W., Ryan, N., \& Willett, R. (2012). Corporate governance in five Arabian Gulf countries. Managerial Auditing Journal, 28(1), 7-22. https://doi. org/10.1108/02686901311282470

5. Bebchuk, L. A., Brav, A., \& Jiang, W. (2015). The LongTerm Effeect of Hedge Fund Activism. Columbia Law Review, 115(5), 1085-1155. Retrieved from https://www.jstor.org/ stable $/ 43582424$ ? seq $=1$ _

6. Becht, M., Franks, J., Mayer, C., \& Rossi, S. (2009). Returns to Shareholders' Activism: Evidence From a Clinical Study of the Hermes UK Focus Fund. The Review of Financial Studies, 22(8), 3093-3129. https://doi. org/10.1093/rfs/hhn054

7. Bhagat, S., \& Bolton, B. (2008). Corporate Governance and Firm Performance. Journal of Corporate Finance, 14(3), 257-273. https://doi.org/10.1016/j.jcorpfin.2008.03.006

8. Bhatt, P. R., \& Bhatt, R. R. (2017) Corporate Governance and Firm Performance in Malaysia. Corporate Governance, 17(5),
896-912. https://doi.org/10.1108/ CG-03-2016-0054

9. Bliss, R. T. (2012). Private Equity: The Differences Between Developed and Emerging Markets. In D. Klonowski (Ed.), Private Equity in Emerging Markets. The New Frontiers of International Finance (pp. 3-16). https://doi. org/10.1057/9781137309433_1

10. Buallay, A., Hamdan, A., \& Zureigat, Q. (2017). Corporate Governance and Firm Performance: Evidence From Saudi Arabia. Australasian Accounting, Business and Finance Journal, 11(1), 78-98. https://doi. org/10.14453/aabfi.v11i1.6

11. Campbell, J. T., Campbell, T., Sirmon, D. G., Bierman, L., \& Tuggle, C. (2012). Shareholder Influence Over Director Nomination Via Proxy Access: Implications for Agency Conflict and Stakeholder Value. Strategic Management Journal, 33(12), 1431-1451. https://doi. org/10.1002/smj.1989

12. Chandren, S., Ahmad, Z., \& Ali, R. (2015). Corporate Governance Mechanisms and Accretive Share Buyback to Meet or Beat Earnings Per Share Forecast. International Journal of Business and Society, 16(3), 344-363. https://doi. org/10.33736/ijbs.572.2015

13. Chauhan, Y., Lakshmi, K. R., \& Dey, D. K. (2016). Corporate Governance Practices, SelfDealings, and Firm Performance: Evidence from India. Journal of Contemporary Accounting \& Economics, 12(3), 274-289. https:// doi.org/10.1016/j.jcae.2016.10.002

14. Cheffins, B. R., \& Armour, J. (2011). The Past, Present, and Future of Shareholders' Activism by Hedge Funds. Journal of Corporation Law, 37, 51-102. Retrieved from https://papers.ssrn. com/sol3/papers.cfm?abstract $\mathrm{id}=1932805$

15. Chung, K. H., \& Zhang, H. (2011). Corporate Governance and Institutional Ownership. Journal of Financial and
Quantitative Analysis, 46(01), 247-273. https://doi.org/10.1017/ S0022109010000682

16. Clapman, P. C. (2005). Shareholder Governance Activism at TIAA-CREF. International Journal of Disclosure and Governance, 2(3), 219-227. https://doi.org/10.1057/palgrave. jdg.2040054

17. Coffee, J., \& Palia, D. (2014). The Impact of Hedge Fund Activism: Evidence and Implications (Law Working Paper No. 266/2014). https://doi.org/10.2139/ ssrn. 2496518

18. Combs, J. G., Ketchen Jr, D. J., Perryman, A. A., \& Donahue, M. S. (2007). The Moderating Effect of CEO Power on the Board Composition-Firm Performance Relationship. Journal of Management Studies, 44(8), 12991323. https://doi.org/10.1111/ j.1467-6486.2007.00708.x

19. Cunat, V., Gine, M., \& Guadalupe, M. (2015). Say Pays! Shareholder Voice and Firm Performance. Review of Finance, 20(5), 17991834. https://doi.org/10.1093/rof/ rfv056

20. Cziraki, P., Renneboog, L., \& Szilagyi, P. G. (2010). Shareholders' Activism through Proxy Proposals: The European Perspective. European Financial Management, 16(5), 738-777. https://doi.org/10.1111/j.1468036X.2010.00559.x

21. Davis, G. F., \& Thompson, T. A. (1994). A Social Movement Perspective on Corporate Control. Administrative Science Quarterly, 39(1), 141-173. https://doi. org/10.2307/2393497

22. Del Guercio, D., Seery, L., \& Woidtke, T. (2008). Do Boards Pay Attention When Institutional Investor Activists "just vote no?" Journal of Financial Economics, 90(1), 84-103. https://doi. org/10.1016/j.jineco.2008.01.002

23. Detthamrong, U., Chancharat, N., \& Vithessonthi, C. (2017). Corporate Governance, Capital 
Structure and Firm Performance: Evidence from Thailand. Research in International Business and Finance, 42, 689-709. https://doi. org/10.1016/j.ribaf.2017.07.011

24. Eisdorfer, A., Giaccotto, C., \& White, R. (2015). Do corporate managers skimp on shareholders' dividends to protect their own retirement funds? Journal of Corporate Finance, 30, 257-277. https://doi.org/10.1016/j.jcorpfin.2014.12.005

25. Ertimur, Y., Ferri, F., \& Muslu, V. (2011). Shareholders' Activism and CEO Pay. The Review of Financial Studies, 24(2), 535592. https://doi.org/10.1093/rfs/ hhq113

26. Filatotchev, I., \& Dotsenko, O. (2015). Shareholders' Activism in the UK: Types of Activists, Forms of Activism, and Their Impact on a Target's Performance. Journal of Management and Governance, 19, 5-24. https://doi.org/10.1007/ s10997-013-9266-5

27. Florackis, C. (2008). Agency costs and corporate governance mechanisms: evidence for UK firms. International Journal of Managerial Finance, 4(1), 37-59. https://doi. org/10.1108/17439130810837375

28. Freeman, R. E., Wicks, A. C., \& Parmar, B. (2004). Stakeholder Theory and The Corporate Objective Revisited. Organization Science, 15(3), 259-374. https://doi. org/10.1287/orsc. 1040.0066

29. Gantchev, N. (2013). The Costs of Shareholders' Activism: Evidence From a Sequential Decision Model. Journal of Financial Economics, 107(3), 610-631. https://doi.org/10.1016/j.jfineco.2012.09.007

30. Gillan, S., \& Starks, L. (2000). Corporate Governance Proposals and Shareholders' Activism: The Role of Institutional Investors. Journal of Financial Economics, 57(2), 275-305. https://doi.org/10.1016/S0304405X(00)00058-1

31. Goranova, M., \& Ryan, L. V. (2014). Shareholders' Activism a Multidisciplinary Review.
Journal of Management, 40(5), 1230-1268. https://doi. org/10.1177/0149206313515519

32. Grewal, J., Serafeim, G., \& Yoon, A. (2016). Shareholders' Activism on Sustainability Issues (Working Paper, No. 17-003). https://doi. org/10.2139/ssrn.2805512

33. Guizani, M. (2014). Controlling Shareholders' Activism Quality and the Disciplinary Role of Dividend. Research Journal of Finance and Accounting, 5(23), 2534 . Retrieved from http://citeseerx. ist.psu.edu/viewdoc/download?d $\mathrm{oi}=10 \cdot 1 \cdot 1 \cdot 663.7230 \& \mathrm{rep}=\mathrm{rep} 1 \& \mathrm{t}$ ype $=$ pdf

34. Hsu, W.-H., Wang, G. Y. Y., Tsai, H., \& Lu, C. (2012). The Moderating and Mediating Effects of Corporate Governance on Firm Performance. In Recent Researches in Applied Computers and Computational Science (pp. 113-119). Retrieved from http:// www.wseas.us/e-library/conferences/2012/Rovaniemi/ACACOS/ ACACOS-17.pdf

35. Jensen, M. C. (1993). The Modern Industrial Revolution, Exit, and the Failure of Internal Control Systems. The Journal of Finance, 48(3), 831-880. https://doi. org/10.1111/j.1540-6261.1993. tb04022.x

36. Jiang, W., \& Anandarajan, A. (2009). Shareholder Rights, Corporate Governance and Earnings Quality: The Influence of Institutional Investors. Managerial Auditing Journal, 24(8), 767-791. https://doi. org/10.1108/02686900910986402

37. Jones, T. M. (1995). Instrumental Stakeholder Theory: A Synthesis of Ethics and Economics. Academy of Management Review, 20(2), 404-437. https://doi. org/10.2307/258852

38. Lafarre, A., \& Van der Elst, C. (2018). Shareholder Sustainability Activism in the Netherlands (Law Working Paper No. 396/2018) (31 p.). European Corporate Governance Institute. https://doi org/10.2139/ssrn.3156614

39. Lee, D. W., \& Park, K. S. (2009). Does Institutional Activism
Increase Shareholder Wealth? Evidence From Spillovers on Non-Target Companies. Journal of Corporate Finance, 15(4), 488-504. https://doi.org/10.1016/j.jcorpfin.2009.03.002

40. Mallin, C. (2012). Institutional Investors: The Vote as a Tool of Governance. Journal of Management and Governance, 16(2), 177-196. Retrieved from https://link.springer.com/article/10.1007/s10997-010-9137-2

41. Narwal, K. P., \& Jindal, S. (2015). The Impact of Corporate Governance on The Profitability: An Empirical Study of Indian Textile Industry. International Journal of Research in Management, Science \& Technology, 3(2), 81-85.

42. Neubaum, D. O., \& Zahra, S. A. (2006). Institutional Ownership and Corporate Social Performance: The Moderating Effects of Investment Horizon, Activism, and Coordination. Journal of Management, 32(1), 108-131. https://doi. org/10.1177/0149206305277797

43. Obermann, J., \& Velte, P. (2018). Determinants and Consequences of Executive CompensationRelated Shareholders' Activism and Say-on-Pay Votes: A Literature Review and Research Agenda. Journal of Accounting Literature, 40, 116-151. https://doi. org/10.1016/j.acclit.2018.02.001

44. Othman, S., \& Borges, W. G. (2015). Shareholders' Activism in Malaysia: Is it Effective? ProcediaSocial and Behavioral Sciences, 172, 427-434. https://doi.org/10.1016/j. sbspro.2015.01.396

45. Parthiban, D., Hitt, M. A., \& Gimeno, J. (2001). The Influence of Institutional Investors in Influencing R\&D. Academy of Management Journal, 44(1), 144157. Retrieved from https://faculty. insead.edu/javier-gimeno/documents/Articles/The-influence-ofactivism-AOMJ-2001.pdf

46. Parthiban, D., Bloom, M., \& Hillman, A. J. (2007). Investor Activism, Managerial Responsiveness, and Corporate Social Performance. Strategic Management Journal, 28(1), 91-100. https://doi.org/10.1002/ smj.571 
47. Pasquali, V. (2015). Shareholders' Activism Is Coming To A Boardroom Near You. Global Finance. Retrieved from https:// www.gfmag.com/magazine/november-2015/shareholder-activism-coming-boardroom-near-you

48. Piesse, J., Strange, R., \& Toonsi, F. (2012). Is There a Distinctive MENA Model of Corporate governance? Journal of Management \& Governance, 16(4), 645-681. https://doi.org/10.1007/ s10997-011-9182-5

49. Proffitt, W. T., \& Spicer, A. (2006). Shaping the Shareholders' Activism Agenda: Institutional Investors and Global Social Issues. Strategic Organization, 4(2), 165-190. https://doi. org/10.1177/1476127006064067

50. Ragas, M. W. (2013). Agenda building during activist shareholder campaigns. Public Relations Review, 39(3), 219-221. https://doi.org/10.1016/j.pubrev.2013.03.007

51. Reid, E. M., \& Toffel, M. W. (2009). Responding to Public and Private Politics: Corporate Disclosure of Climate Change Strategies. Strategic Management Journal, 30(11), 1157-1178. https://doi. org/10.1002/smj.796

52. Rubach, M. J., \& Sebora, T. C. (2009). Determinants of Institutional Investor Activism: A Test of the Ryan-Schneider Model (2002). Journal of Managerial Issues, 21(2), 245-261.
Retrieved from www.jstor.org/ stable/40604646

53. Santiago-Castro, M., \& Brown, C. J. (2007). Ownership structure and minority rights: A Latin American view. Journal of Economics and Business, 59(5), 430-442. https://doi.org/10.1016/j.jeconbus.2007.04.005

54. Sharfman, B. S. (2014). A Theory of Shareholders' Activism and Its Palce in Corporate Law. Tennessee Law Review, 82, 791. Retrieved from https://heinonline.org/HOL/ LandingPage?handle=hein.journals/tenn $82 \&$ div $=36 \&$ id $=$ \&page $=$

55. Singh, S., Tabassum, N., Darwish, T. K., \& Batsakis, G. (2017). Corporate Governance and Tobin's $\mathrm{Q}$ as a Measure of Organizational Performance. British Journal of Management, 29(1), 171-190. https://doi. org/10.1111/1467-8551.12237

56. Souha, S. B., \& Anis, J. (2016). Corporate Governance and Firm characteristics as Explanatory Factors of Shareholders' Activism: Validation Through the French Context. Cogent Economics \& Finance, 4(1), 1150407. https:// doi.org/10.1080/23322039.2016.1 150407

57. Sulong, Z., \& Nor, F. M. (2010). Corporate Governance Mechanisms and Firm Valuation in Malaysian Listed Firms: A Panel Data Analysis. Journal of Modern Accounting and Auditing, 6(1), 1-18.
58. Sunder, J., Sunder, S. V., \& Wongsunwai, W. (2014).

Debtholder Responses to Shareholders' Activism: Evidence from Hedge Fund Interventions. The Review of Financial Studies, 27(11), 3318-3342. https://doi. org/10.1093/rfs/hhu049

59. Thomas, R. S., \& Cotter, J. F. (2007). Shareholder Proposals in the New Millennium: Shareholder Support, Board Response, and Market Reaction. Journal of Corporate Finance, 13(2-3), 368391. https://doi.org/10.1016/j. jcorpfin.2007.02.002

60. Welker, M., \& Wood, D. (2011). Shareholders' Activism and Alienation. Current Anthropology, 52, 57-69. https://doi. org/10.1086/656796

61. Zabri, S. M., Ahmad, K., \& Wah, K. K. (2016). Corporate Governance Practices and Firm Performance: Evidence From top 100 Public Listed Companies in Malaysia. Procedia Economics and Finance, 35, 287-296. https://doi.org/10.1016/S22125671(16)00036-8

62. Zeng, Y., Yuan, Q., \& Zhang, J. (2011). Dark Side of Institutional Shareholders' Activism in Emerging Markets: Evidence From China's Split Share Structure Reform. Asia-Pacific Journal of Financial Studies, 40(2), 240-260. https://doi.org/10.1111/j.20416156.2011.01041.x 